\title{
Determinant of Access to Rural Credit and Its Effect on Living Standard: Case Study about Poor Households in Northwest, Vietnam (Note 1)
}

\author{
Tran Thi Thanh $\mathrm{Tu}^{1}$, Nguyen Quoc Viet ${ }^{2} \&$ Hoang Huu Loi ${ }^{1}$ \\ ${ }^{1}$ Faculty of Finance and Banking, VNU University of Economics and Buisness, Vietnam \\ ${ }^{2}$ Faculty of Development Economics, VNU University of Economics and Business, Vietnam \\ Correspondence: Dr. Tran Thi Thanh Tu, Associate Professor, Faculty of Finance and Banking, VNU University of \\ Economics and Business, Vietnam. E-mail: tuttt@vnu.edu.vn \\ Received: March 31, 2015 \\ Accepted: April 16, 2015 \\ Online Published: April 19, 2015 \\ doi:10.5430/ijfr.v6n2p218 \\ URL: http://dx.doi.org/10.5430/ijfr.v6n2p218
}

\begin{abstract}
This study investigated the determinants of accessibility to formal credit and its effects on living standards from 2010 to 2012 based on dataset of Vietnam Households Living Standards Survey (VHLSS) from the General Statistics Office of Vietnam and support of Eview 7 program. It is evident that average of education level, land area per capita, owned residential area affect is key factors of accessing to credit; meanwhile, average of education level affects the probability to require and amount of credit. Interestingly, we find that poor recognize by local and rate of non-farm income is positive factor of accessibility on formal credit; in addition, interest rate has statistically significant, implying has impact on loan amount. In otherwise, by using DID (Note 2) approach and OLS (Note 3) model for analyzing panel dataset in 2010,2012; we find that have only impact of accessing to loan on education expense in short-term. Next, the results also indicate that enhance education level and rate of non-agriculture income lead to achievement of living standards.
\end{abstract}

Keywords: rural credit, poverty reduction, poor household, Northwest of Vietnam

\section{Introduction}

Economic development for ethnic minority is one of priority policy of government of Vietnam. Their objective not only - improves living standard, income capita, reduce poverty rate, but also towards and equiable society, democracy and civilization. To achieve this objective, the Vietnam Goverment has promulgated and implemented many policies, programs and projects to meet the requiment of regional development. Credit for the poor ethnic minority households with preferential interestrate is stark example, in order to achieve agriculture production, raising incomes, and to give greater oppotunities for faster and sustainable poverty reduction. This is also the experience of poverty reduction which has been done in many countries around the world, especially - developing countries in Asia, South Africa, the Middle East and Latin America.

The benefits and impacts of rural credit for poverty alleviation have been given much interest by scholars and researchers in many countries around the world. Many studies show - accessing to credit of poor households will increase productivity, create jobs, welfare. These results have been confirmed in several studies of Morduch (1995); Gulli (1998); Khandker (1998); Pitt and Khandker (1998); Zeller (2000); ADB (2000). In addition, the other impact of credit programs for the poor is positively effective to living standard of children on the poor households, namely nutrition, health care, education, labor hours of children (Lire Ersado (2003); Nobuhiko Fuwaet al. (2009).

Northwest Vietnam is characterized specially by the terrain which is mostly mountainous, the high percentage of ethnic minorities and also areas of difficulty in all aspects of economic, social, and highest poverty rate. Therefore, the research on development policy in Northwest region is also the policy implications for the development of ethnic minority groups, which has been assessed as vulnerable groups. Recently years, throughout government issued policies on the economy, culture, health, education; Northwest region has made significant achievements such as economic growth, poverty reduction by annual average rate of $2-2.5 \%$. However, the process of development has many drawbacks, the poverty rate has declined, but still the highest rate in country with a $21.54 \%$ (Note 4 ) in 2012 , low economic growth rate, short in income capita, the effective implementation of programs and projects for sustainable poverty reduction in the area have not been success as targeted. One of the causes of negative impacts on poverty reduction is constrain access to credit by the poor households (UNDP, 2012). Therefore, the research 
"Determinant of access to rural credit and its effects on living standard: Case study about poor households in Northwest, Vietnam" was selected for study.

Our objectives are describing and measuring the factors of accessing to credit by the poor ethnic minority households; elaborating on the relationship on access to credit and living standard of the poor households. Then, we will draw some recommendations to enhance accessing to credit. Specifically, the study addresses two research questions:

(i) What factors affect access to credit for poor households in rural Northwest?;

(ii) What impact of accessing to credit on living standard of the poor households?

To answer those questions, the study uses a probabilistic model as Probit model and Tobit model to evaluate the factors affecting access to credit by poor households. In addition, we apply difference in difference (DID) method in OLS regression to test the impact of accessibility to credit on income and expenditure of poor households. The data used for this study are from the two Vietnam Household Living Standard Surveys taken in 2010 and 2012.

\section{Literature Review and Rural Credit Market in Northwest Area in Vietnam}

\subsection{Rural Credit Market in Northwest Area}

Figure 1describes rural credit market in Northwest area, which has the same characteristics as the rural credit system of the country and rural credit systems in many other countries around the world. Rural credit market in Northwest area can be divided into three groups: formal credit, informal credit and semi-formal credit.

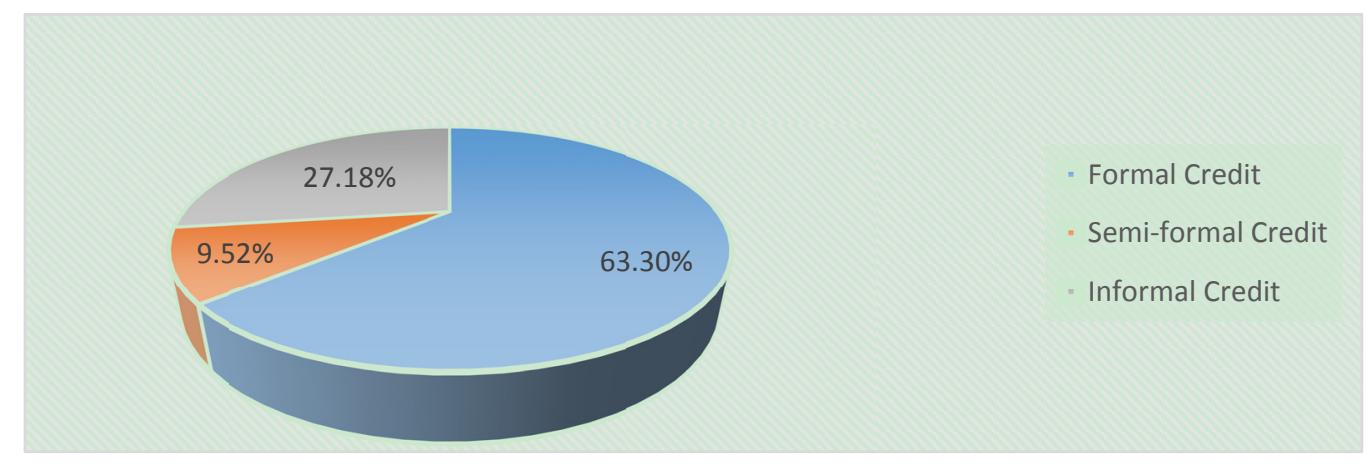

Figure 1. Rural credit market in Northwest area (Note 5)

Source: Authors calculations based on VHLSS (2008)

The figure on credit market in rural Northwest is constructed on the results of data analysis from VHLSS (2008). Formal credit is greater of important in rural credit market Northwest with 63.30 percentages of market (Figure 1). Informal credit supply, is the second largest source with about $27.18 \%$, which is characterized by a simple loan procedures, not require high collateral, the interest rate of the loan is very flexible, can be high up to $10-20 \% /$ per month if the borrower from loan individual households but can be very low $0 \%$ if borrowing from relatives or friends (Nguyen, 2010). Semi-formal credit is smallest credit source, that capital is funded by Non-government Organization (NGOs), foreign organizations, development fund under special programs or projects.

For research objective, our paper focused on the characteristics of formal credit and access to formal credit of poor ethnic minority households in Northwest area.

The Vietnam Bank for Agriculture and Rural Development (VBARD) and the Vietnam Bank for Social Policies (VBSP) are the two main providers of formal credit to households in the rural in Northwest. The main activity of the VBARD is agricultural lending and farmer which is great of its customers. The main role of VBSP is providing capital for beneficiaries under the program, projects such as poor households program, job creation program, program for business and production households living in extremely disadvantaged areas and communes. The VBSP provides credit in two forms. People can borrow directly from its branches or via social economics unions. The most important unions for VBSP lending are Farmer's Union, Women's Union, Youth's Union and War Veteran's Union (Vuong, 2012). 
Table 1. Loan characteristics by two banks VRARD and VBSP

\begin{tabular}{lcccc}
\hline & Average & The VBARD & VBSP & T-test \\
\hline Loan amount & 10525.31 & $13225)$ & 8441.333 & $5.9584^{*}$ \\
$(1,000$ VND) & $(8281.598)$ & $(9928.286)$ & $(5977.363)$ & \\
Interest rate & 9.216792 & 12.58678 & 6.610667 & $20.763^{*}$ \\
$(\% /$ year) & $(4.112500)$ & $(3.782818)$ & $(1.831513)$ & \\
Loan duration & 35.74687 & 32.33908 & 38.38222 & $-4.3926^{*}$ \\
(Months) & $(13.93735)$ & $(15.21655)$ & $(12.26041)$ & \\
\hline \hline
\end{tabular}

Notes: Standard deviation in parentheses, $(*)$ Significant at $1 \%$

The results of T-test in Table 1 show that the differences in loan characteristics by two banks as VRARD and VBSP at the $1 \%$ level of significance. The VBARD offers larger loans amount $(13,220$ thousand VND on average) than VBSP with 8,441 thousand VND while VBARD charges higher interest rate (12.59\%/year) than the VBSP with $6.61 \%$ year - from VBSP is reasonable with the poor households, whose capital demand is low and scale of business is also small.

\subsection{Literature Review}

\subsubsection{Literature Review about Determinant of Accessing to Credit}

According to Zeller (2001) a household has particular credit accessing if it is able to borrow from that source, although for a variety of reasons it may choose not to. So that a household credit constrained is a lack of accessing to credit or "cannot borrow as much as it wants".

In many previous studies, using measurable coefficients of explanatory variables in econometric models, the determinants of accessing to credit can be divided into three main groups: household's natural characteristic, household's labor characteristic and local market characteristic.

Household's natural characteristic inlude the age of the household head, household size, gender of the household head, and ethnic factor. Findings many research showed - the age of household head, household size and ethnic majority have positive impact on household's ability to access to credit (Quach, 2005; Vuong, 2012). It's easier for households having older households in approaching credit; however, as these households have lower demand, they usually produce and run business in low risk fields, need little capital, so the demand for fund is also lower (Mikkel Barslund and Finn Tarp, 2002). Ethnic group of household affects borrowing fund in negative way. Households belong to minorities are usually restricted in accessing to credit because of barriers in geography and low education (Vuong, 2012).

Household's labor characteristics include owned farm land, education level, residential land, etc. Owned farm land and education level have positive impacts on accessing to credit as well as the amount of fund household can receive. If the households have high education level, they can apply science and technology to improve productivity and accommodate with the risk in production process. Furthermore, high education level makes it easier for the household to get information from credit organization (Zeller, 2001). Poor households belong to minorities usually have low education, which is disadvantage for them to access fund sources, lacking of collateral - main reason leading to limitation for poor households in accessing to credit (Zeller, 2001; Quach, 2005; Vuong, 2012; Khandker, 2009).

Local market characteristic, previous researches showed that besides market factors; characteristics of culture, politics and social network, and poverty rate in the region also affect the poverty's participation in official credit market (MikkelBarslund and Finn Tarp, 2008). Two other factors also are used which are poor records and loans' interest. Poor record is an important legal procedure that poor households can use to access fund resource from formal credit or poverty reduction programs.

\subsubsection{Impacts of Credit on Welfare of Poor Households}

Capital is an important input factor in production process, so lacking capital means household's production is limited, which leads their income to be reduced. Borrowing fund resource can help poor households expand their production and as a result - the income is increased.

The impacts of credit on poor households' welfare include household's income, expenditure on food, expenditure on education, and expenditure on health care. Many research show the accessing to credit is the important condition for the poor to improve production, health care, education (Quach, 2005; David, 2012, Vuong 2012...). Some researches in Africa and Asia - as of Zeller (2001), Khandker (2005), Morduch (2005), Barbara Haley (2002) argued that the 
great of important of granting credit with favor conditions for the poor, to help them get out of poverty. Copestake and Blalotra (2000) found that loan for the poor will help them do for themselves and have fund to do some small businesses, which provide opportunities for them to get out of poverty.

\subsubsection{Impacts of Credit in Sustainable Poverty Reduction}

Although upon now there has been no evidence or research in long-term to evaluate the impacts of credit on sustainable poverty reduction. Based on double impact between the impact of credit on poor household's welfare and the influence of factor that are favor from credit on income of the households, many authors determined that is the ground for the poor to get out of poverty sustainable. Khandker (2005), Vuong (2012), Nobuhiko Fuwa (2009), David (2012), WB (2004) argued that investments for education, health care and improve living standard of the children are basis to help the poor households back out poverty sustainable.

\section{Methodology and Model}

\subsection{Econometric Model}

\subsubsection{Econometric Model in Previous Research}

a. M.H Quach, A.W. Mullineux, V. Muride (2005). research about factor of accessibility to credit of rural households Vietnam in period 1992/1993 and 1997/1998, analysis team used Tobit model:

$$
C_{i}^{d *}=\beta^{d}+X_{1}^{\prime} \beta_{1}^{d}+X_{2}^{\prime} \beta_{2}^{d}+W_{d}^{\prime} \beta_{w}^{d}+\varepsilon_{i} \text { in which }\left(\left(\varepsilon_{i} \mid X_{i} \sim N\left(0, \sigma^{2}\right)\right)\right.
$$

Where: $\boldsymbol{C}_{\boldsymbol{i}}^{\boldsymbol{d} *}$ is total household's loan; $\boldsymbol{X}_{\mathbf{1}}^{\prime}$ is vector of household characteristics (age of household head, gender of household head, education level of household head, household size, the ownership of farm land, etc.); $\boldsymbol{X}_{2}^{\prime}$ is a vector of local market characteristics (the prices of selected good and services, average education level, fram landlevels etc.); $\boldsymbol{W}_{\boldsymbol{d}}^{\prime}$ is a vector of unobservable characteristics of households.

b. VuongQuocDuy et al. (2012) study of determinants of accessing to formal credit of households in Mekong delta region, Vuong used Heckman selection model to analyze:

$$
Y_{i}=\beta_{i} X_{i}+v_{i}
$$

Where: $Y_{i}$ is value of loans, $X_{i}$ is vector explanatory variables include: the age of household head, gender of household hear,education level, religion, marital status, Vietnamese ethnic, family size, dependency ratio in percent, total land in use, Red certificate of land use right, the value of building hold by households.

c. Mikkel Barslund and Finn Tarp (2003), uses Probit model to research which factors effect on borrowing credit with model:

$$
P(\text { demand }=1)=F\left(H_{i} ; X_{c} ; D_{p}\right)
$$

Where:

$H_{i}$ : is vector of household characteristics (age, total land, gender, education level, dependency ratio, total assets, red book (land certificate))

$X_{c}$ : captures village characteristics (distance to district centre in $\mathrm{km}$ )

$D_{p}:$ represents province dummies.

\subsubsection{Method and Econometric Model}

\section{a. Testing determinant of access to credit by Probit and Tobit model}

For the first research objective that determinant of access to credit by poor households in Northwest; Probit and Tobit model two models, which are applied for these.

Probit model is used to determine the factors affecting probability to require formal credit by the poor.

Probit model:

$$
y_{i}^{*}=\beta_{0}+\sum_{j=1}^{k} \beta_{j} X_{i j}^{\prime}+u_{i}
$$

Where:

$y_{i}^{*}$ : Dummy variable. $\mathrm{Y}=1$ if households borrow from formal credit in $2012, \mathrm{Y}=0$ if households is non-borrower in 2012.

$X_{i j}^{\prime}$ : is the vector of explanatory variables $\left[X_{i 1}^{\prime} ; X_{i 2}^{\prime} ; X_{i 3}^{\prime} ; X_{i 4}^{\prime}\right]$ including $X_{i 1}^{\prime}$ is household's natural characteristic; $X_{i 2}^{\prime}$ is household's labour characteristic; $X_{i 3}^{\prime}$ is local market characteristic. 
Tobit model studies the relationship between the degrees (quantity) of dependent variables fluctuate with the independent variables. In this study, Tobit model to use to investigate the factors that affect the loan amount of poor households.

Tobit model:

$$
C_{i}=c^{*}=\left\{\begin{array}{lr}
\alpha_{1}+\alpha_{k} X_{i k}^{\prime}+u_{i} & \text { if } c^{*}>0 \\
0 & \text { otherwise }
\end{array}\right.
$$

Where:

$C_{i}$ : is dependent variable that is value of loan.

$X_{i k}^{\prime}$ : is a vector of explanatory variables including $X_{i 1}^{\prime}$ is household's natural characteristic; $X_{i 2}^{\prime}$ is household's labour characteristic; $X_{i 3}^{\prime}$ is local market characteristic.

\section{b. Testing impact of access credit on living standards by DID model}

Estimate the difference in difference (DID) is a popular method of natural experiments. This method applies to panel data which contains information about cross different objects and information over time. In this method, the poor households is divided into two groups, group policy applied (treatment group), group policy not applied (control group). $\mathrm{D}$ is dummy variable: $\mathrm{D}=0$ is control group; $\mathrm{D}=1$ is treatment group.

A great of important assumption of the DID method is the two groups have similar characteristics to the period before the policy applies. Thus the output of two groups tends to have similar variability over time if there is no policy.

Assume: variable $\mathrm{Y}$ is output of the credit policy (income, expenditure). $\mathrm{T}$ is dummy variable: $\mathrm{T}=0$ is the time before the policy, $\mathrm{T}=1$ is after the policy.

At the time prior to the policy, the output of control group is $\mathrm{Y}_{00}(\mathrm{D}=0, T=0)$, the output of treatment group is $\mathrm{Y}_{10}$ $(D=1, T=0)$. Difference in output between two groups equal: $\mathbf{Y}_{\mathbf{1 0}}-\mathbf{Y}_{\mathbf{0 0}}$.

At the time of the policy, the output of control group is $Y_{01}(D=0, T=1)$, the output of treatment group is $\mathbf{Y}_{11}(\mathrm{D}=1$, $\mathrm{T}=1$ ). Meanwhile, the output difference between two groups is $\mathbf{Y}_{\mathbf{1 1}}-\mathbf{Y}_{\mathbf{0 1}}$.

Impact of policy equal by DID method: $\left(\mathbf{Y}_{11}-\mathbf{Y}_{\mathbf{0 1}}\right)-\left(\mathbf{Y}_{10}-\mathbf{Y}_{\mathbf{0 0}}\right)$.

For research objective, DID method is used to study about impact of rural credit on living standards of poor households; meanwhile, preferential credit is policy. Two groups were selected by accidental that reasonable DID theory namely treatment group and control group. Treatment group is poor household that borrowed in 2012, but not in 2010. In addition, control group is poor household that did not borrow in both 2010 and 2012.

However, household income is a function of multiple variables with many variable other than credit. Thus, research results is completely when control variables were used in research model such as average education level, rate of non-farm income, land area per capita... Research model is by DID method in OLS regression:

$$
\mathrm{Y}_{\text {it }}=\beta_{0}+\beta_{1} \mathrm{~B}+\beta_{2} \mathrm{~T}+\beta_{3} \mathrm{~B} * \mathrm{~T}+\beta_{4} \mathrm{~K}_{\mathrm{it}}+\varepsilon_{\mathrm{it}}
$$

Where, $\mathbf{Y}_{\mathbf{i t}}$ is an indicator reflecting living standards of household $i$ at time $t$

$\mathrm{D}=1$ : Household in treatment group; $\mathrm{D}=0$ : household in control group.

$\mathrm{T}=0$ : household surveyed in 2010; $\mathrm{T}=1$ : Household surveyed in 2012

$\mathrm{K}_{\mathrm{it}}$ is control variables: household size, average level education, rate of non-farm income, land area per capita...

+ Household living standards of control group in $2010(\mathrm{D}=0, \mathrm{~T}=0): \mathrm{E}\left(\mathrm{Y}_{00}\right)=\widehat{\beta_{0}}+\widehat{\beta_{4}} \mathrm{~K}_{\mathrm{it}}$

+ Household living standards of treatment group in $2010(\mathrm{D}=1, \mathrm{~T}=0): \mathrm{E}\left(\mathrm{Y}_{10}\right)=\widehat{\beta_{0}}+\widehat{\beta_{1}}+\widehat{\beta_{4}} \mathrm{~K}_{\mathrm{it}}$

- Differences in household living standards between the two groups in 2010: $\mathrm{E}\left(\mathrm{Y}_{10}\right)-\mathrm{E}\left(\mathrm{Y}_{00}\right)=\widehat{\beta_{1}}$

+ Household living standards of control group in $2012(\mathrm{D}=0, \mathrm{~T}=1): \mathrm{E}\left(\mathrm{Y}_{01}\right)=\widehat{\beta_{0}}+\widehat{\beta_{2}}+\widehat{\beta_{4}} \mathrm{~K}_{\mathrm{it}}$

+ Household living standards of treatment group in $2012(\mathrm{D}=1, \mathrm{~T}=1): \mathrm{E}\left(\mathrm{Y}_{11}\right)=\widehat{\beta_{0}}+\widehat{\beta_{1}}+\widehat{\beta_{2}}+\widehat{\beta_{3}}+\widehat{\beta_{4}} \mathrm{~K}_{\mathrm{it}}$

D Differences in living standards between the two groups in 2012: $\mathrm{E}\left(\mathrm{Y}_{11}\right)-\mathrm{E}\left(\mathrm{Y}_{01}\right)=\widehat{\beta_{1}}+\widehat{\beta_{3}}$

Impact of credit on living standards of poor households:

$$
\left[\mathrm{E}\left(\mathrm{Y}_{11}\right)-\mathrm{E}\left(\mathrm{Y}_{01}\right)\right]-\left[\mathrm{E}\left(\mathrm{Y}_{10}\right)-\mathrm{E}\left(\mathrm{Y}_{00}\right)\right]=\widehat{\beta_{3}}=\mathrm{DID}
$$

Thus, the estimated coefficient $\widehat{\boldsymbol{\beta}_{3}}$ (or coefficient of $\left(\mathrm{B}^{*} \mathrm{~T}\right.$ ) variable) in the model Mod.3 is the impact of credit to poor living standards. 


\subsection{Definition Variable}

To analyze factors of accessing to credit by poor household, some variable was used in econometric such as previous research; in addition, new explanatory variable is used also that have been no studies in Vietnam, to the best of our knowledge.

Table 2. Variable definitions Mod.1; Mod.2; Mod.3

\begin{tabular}{|c|c|c|c|c|}
\hline Variable & Definitions & Model & Expection & Year \\
\hline \multicolumn{5}{|c|}{ Dependent Variable } \\
\hline Credit & $\begin{array}{l}\text { Dummy variable: Borrowers }=1 \text {, Non Borrowers } \\
=0 \text {. }\end{array}$ & Mod.1 & & 2012 \\
\hline Total_credit & Value of the loan (VND 1,000) & Mod.2 & & 2012 \\
\hline IncomePer & 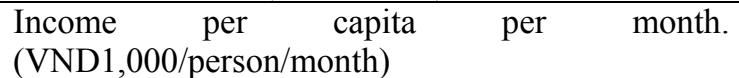 & Mod.3 & & $\begin{array}{l}2010, \\
2012\end{array}$ \\
\hline FoodExp & $\begin{array}{l}\text { Per capita food expenditure per } \\
\text { (VND1,000/person/month) }\end{array}$ & Mod.3 & & $\begin{array}{l}2010, \\
2012\end{array}$ \\
\hline HealthExp & Expenditure on health care (VND 1,000) & Mod.3 & & $\begin{array}{l}2010, \\
2012\end{array}$ \\
\hline EduExp & Expenditure on education (VND 1,000). & Mod.3 & & - \\
\hline \multicolumn{5}{|c|}{ Explanatory variables } \\
\hline Age & The age of household head & Mod.1,2.3 & $-1+$ & 2012 \\
\hline Gend & $\begin{array}{l}\text { Dummy variable: gend of household head: male } \\
=1 \text {; female }=0 .\end{array}$ & & + & $\begin{array}{l}2012 \\
2010\end{array}$ \\
\hline$E d u_{-}$ & Education level of household head (Year) & & + & $\begin{array}{l}2012 \\
2010\end{array}$ \\
\hline Minothic & Vietnamese ethnic, KinhHoa $=0,1$ otherwise & & - & 2012 \\
\hline Hunger & $\begin{array}{l}\text { Numbers of month of household food shortage in } \\
\text { year (month) }\end{array}$ & & + & 2012 \\
\hline Edu_average & $\begin{array}{l}\text { Average level education of household, is calculated } \\
\text { by total education level per size. (Year) }\end{array}$ & & + & $\begin{array}{l}2012 \\
2010\end{array}$ \\
\hline PoorHH & $\begin{array}{l}\text { Dummy variable. The recognition of poor } \\
\text { households by local. Yes }=1, \mathrm{No}=0\end{array}$ & & & \\
\hline Size & Number of household members (person) & & + & $\begin{array}{l}2010, \\
2012\end{array}$ \\
\hline House & $\begin{array}{l}\text { Total value of the house hold by household. (VND } \\
1,000 \text { ) }\end{array}$ & & + & $\begin{array}{l}2010 \\
2012\end{array}$ \\
\hline HHSquare & Total size of residential area $\left(\mathrm{m}^{2}\right)$. & & + & 2012 \\
\hline SquarePer & Land area per capita of household ( $\mathrm{m}^{2} /$ person). & & + & 2012 \\
\hline NonAgr & Rate of non-farm income $(\%)$. & & + & 2012 \\
\hline Depend & Dependency ratio (\%) & & - & 2012 \\
\hline Industry & $\begin{array}{l}\text { Dummy variable: agrarian household }=1 \text {, otherwise } \\
=0 \text {. }\end{array}$ & & - & 2012 \\
\hline Interest & Interest rate for formal credit (\%) & & - & 2012 \\
\hline HHIncome & Total income (VND 1,000). & & - & 2012 \\
\hline LivestockExpi & Livestock expenses of household (VND 1,000). & Mod.2 & + & 2012 \\
\hline FosteryEXp & Forestry expenses of household (VND 1,000). & Mod.2 & + & 2012 \\
\hline FarmExp & Farming expenses of household (VND 1,000). & Mod.2 & + & 2012 \\
\hline
\end{tabular}

New explanatory variable is namely:

Poorer recognition by local is dummy variable in both Mod.1 and Mod 2 model. Since the poor recognition is significant, legal procedure that gives greater chances to poor households accessing to loan from preferential credit programs of government or international organizations.

Non-farm income rate is the income from the non-farm sources of total household income. This variable was used in model to test a hypothesis: those working in non-agricultural sector have higher probability accessing to loan than other groups.

Number of months of food shortage is a new variable has not been studied in literature, to the best of our knowledge. 


\section{Data}

Our paper used two datasets from Vietnams household living standard surveys (VHLSS), which were conducted by the General Statistical Office of Vietnam (GSO) with technical support from the World Bank and UNDP for the year 2010 and 2012.The survey was conducted nationwide involving a sample scale of 69,360 and 46,996 household's observations for 2010 and 2012 respectively; in which, half of households from 2012 took part survey in 2010.

The poor households were based on the poverty standard defined by Ministry of Labor and Social Affairs in 2012 that were 400 thousand VND per person per month in rural and 500 thousand VND per person per month in urban.

The results showed that 1011 poor households in Northwest, including 463 poor households borrowing preferential credits.

Table 3. Statistical summary of Model Mod.1

\begin{tabular}{lccc}
\hline \multicolumn{1}{c}{ Variables } & Mean & Median & Std. Dev \\
\hline Age & 43.24629 & 41.00000 & 13.38943 \\
HHSquare & 62.20673 & 60.00000 & 25.80072 \\
Depend & 0.529515 & 0.400000 & 0.525843 \\
Edu_average & 4.018666 & 3.800000 & 2.416773 \\
SquarePer & 2676.336 & 1631.800 & 4047.341 \\
Edu & 4.013848 & 4.000000 & 3.486297 \\
House & 81591.79 & 60000.00 & 84247.54 \\
NonAgr & 0.274680 & 0.200579 & 0.234243 \\
Hunger & 0.636004 & 0.000000 & 1.221122 \\
Size & 4.962413 & 5.000000 & 1.883900 \\
Income & 27266.00 & 24781.00 & 12849.07 \\
\hline \hline
\end{tabular}

Table 3 described poor characteristics of Northwest region with detail such as lower average education level (about 4.01 year per person). Households principal income is from agricultural production, the rate of non-farm income averaged $27.46 \%$; moreover, the standard deviation of the ratio of non-farm income is $23.42 \%$ close to the average value, these mean that non-agricultural activities are shortage in the livelihoods of poor households in the Northwest.

Table 4. Household characteristics

\begin{tabular}{|c|c|c|c|}
\hline & $\begin{array}{c}\text { Non borrowers } \\
(564)\end{array}$ & $\begin{array}{c}\text { Borrowers } \\
(447)\end{array}$ & $T$ - test \\
\hline Age & $\begin{array}{c}44.533 \\
(14.065)\end{array}$ & $\begin{array}{c}41.621 \\
(12.309)\end{array}$ & $3.4526^{*}$ \\
\hline HHSquare & $\begin{array}{c}60.067 \\
(24.283)\end{array}$ & $\begin{array}{c}64.906 \\
(27.387)\end{array}$ & $-2.9829 *$ \\
\hline Depend & $\begin{array}{c}0.5147 \\
(0.5120)\end{array}$ & $\begin{array}{c}0.5481 \\
(0.5428)\end{array}$ & -1.0056 \\
\hline Edu_average & $\begin{array}{c}3.7907 \\
(2.3496)\end{array}$ & $\begin{array}{c}4.3063 \\
(2.4717)\end{array}$ & $-3.3866 *$ \\
\hline SquarePer & $\begin{array}{c}2747.9 \\
(4538.9)\end{array}$ & $\begin{array}{c}2585.9 \\
(3327.8)\end{array}$ & 0.6319 \\
\hline$E d u_{-}$ & $\begin{array}{c}3.7570 \\
(3.4727)\end{array}$ & $\begin{array}{c}4.3378 \\
(3.4802)\end{array}$ & $-2.6381 *$ \\
\hline House & $\begin{array}{c}80004.26 \\
(78443.31)\end{array}$ & $\begin{array}{c}83594.85 \\
(91095.38)\end{array}$ & -0.6728 \\
\hline NonAgr & $\begin{array}{c}0.2599 \\
(0.2303)\end{array}$ & $\begin{array}{c}0.2934 \\
(0.2379)\end{array}$ & $-2.2667 * *$ \\
\hline Hunger & $\begin{array}{c}0.6241 \\
(1.3114)\end{array}$ & $\begin{array}{c}0.6510 \\
(1.0979)\end{array}$ & -0.3476 \\
\hline Size & $\begin{array}{l}4.9645 \\
(2.0305)\end{array}$ & $\begin{array}{c}4.9597 \\
(1.6830)\end{array}$ & 0.0403 \\
\hline Income & $\begin{array}{c}26920.89 \\
(13375.54)\end{array}$ & $\begin{array}{c}27701.45 \\
(12153.19)\end{array}$ & -0.9593 \\
\hline
\end{tabular}

Notes: Standard deviation in parentheses; $\left.(*),{ }^{* *}\right)$ significant at $1 \%, 5 \%$ 
There are some differences in characteristics of borrower and non-borrower. From Table 4, T-test shows that borrower is greater of in level education of household head, average education level, size of living area, rate of non-farm income than non-borrower; meanwhile, age of household head trends is opposite. Briefly, size of residential area has been considered an important determinant of access to credit (Okurut, 2006; Zeller et al, 2001) as this land can be used as collateral for the loan. It is hypothesized that households with high age of households head often produce in low-risk areas is more likely have low capital demand and a lower probability of borrowing (MikkelBarslund and Finn Tarp, 2002).

Research assumptions were made which were reasonable for DID method in which every household assumed to have loan accessibility equally. The results showed been classified as poor by local that is equally in benefit if credit policy was applied. Our research result shows that for accessing to credit in Northwest described 28 poor households has been borrowed preferential loan in 2012 but not in 2010; it was relevant that 64 poor households have not been accessed loan in both 2010 and 2012.

Table 5. T-test result

\begin{tabular}{lcrrrrrr}
\hline \multirow{2}{*}{$\mathrm{N}$} & \multicolumn{2}{c}{ Treatment group in 2010 } & \multicolumn{2}{c}{ Control group in 2010 } & \multirow{2}{*}{ T-test } \\
\cline { 2 - 6 } & Obs & Mean $_{1}$ & Std.Dev & Obs & Mean $_{2}$ & \multicolumn{1}{c}{ Std.Dev } & \\
\hline Age & 28 & 35.071 & 8.214 & 64 & 41.109 & 13.831 & 2.146 \\
\hline Size & 28 & 4.786 & 1.873 & 64 & 5.031 & 2.160 & $-0.521 *$ \\
\hline Edu & 28 & 5.036 & 2.912 & 64 & 3.781 & 3.369 & $1.710^{*}$ \\
\hline Edu_average & 28 & 4.192 & 2.232 & 64 & 3.207 & 2.328 & $-1.891^{*}$ \\
\hline NonAgr & 28 & 0.257 & 0.284 & 64 & 0.255 & 0.215 & $-0.052^{*}$ \\
\hline HHSquare & 28 & 1798.963 & 1491.829 & 64 & 2162.773 & 2003.155 & $0.861^{*}$ \\
\hline EduExp & 28 & 636.536 & 801.471 & 64 & 410.063 & 854.459 & $-1.191^{*}$ \\
\hline FoodExp & 28 & 509.029 & 287.600 & 64 & 442.883 & 161.794 & $1.405^{*}$ \\
\hline HealthExp & 28 & 3309.429 & 13815.96 & 64 & 524.141 & 1281.572 & $-1.608^{*}$ \\
\hline Income & 28 & 350.250 & 152.418 & 64 & 295.453 & 92.135 & $-2.128^{*}$ \\
\hline
\end{tabular}

Notes: *: Hypothesis $\left\{\begin{array}{l}H_{0}: \operatorname{Mean}_{1}=\operatorname{Mean}_{2} \\ H_{1}: \operatorname{Mean}_{1} \neq \operatorname{Mean}_{2}\end{array}\right.$ and Hypothesis $\mathrm{H}_{0}$ is rejected at $1 \%$ significant.

From Table 5, By T-test similarity of the two groups, we found similarities in household size, education level of household head, average of education level, the proportion of non-farm income, land area per capita, expenditure on education, expenditure on health care, income. The two groups differ only on the age of the household head. It is a reasonable assumption that lack of credit as result of two groups will have the same development trend.

\section{Empirical Result}

\subsection{Determinant of Accessing to Rural Credit by Poor Rural Households}

\section{a. Result from Probit model}

Considering the result from probit model sample from Table 6 , we find that, at the $1 \%$ level of significance, determinant of accessing to loan is poor recognition of households by local, average of education level, rate of non-farm income, total living area, and age of household head.

Table 6. Determinants of access to formal rural credit by Probit Regression

\begin{tabular}{lcc}
\hline Dependent variable & \multicolumn{2}{c}{ Credit } \\
\hline Explanatory variables & Coefficient & z-Statistic \\
\hline C & $\mathbf{- 1 . 2 0 2 3 1 1 *}$ & -3.350376 \\
Age & $\mathbf{- 0 . 0 1 2 5 2 1 *}$ & -3.462245 \\
Gend & 0.120750 & 0.874132 \\
Size & 0.012510 & 3.360539 \\
Minothic & 0.226443 & 1.337884 \\
Edu_ & -0.001895 & -0.122568 \\
Edu_average & $\mathbf{0 . 0 7 7 1 2 2 *}$ & 3.359061
\end{tabular}




\begin{tabular}{lcc} 
Depend & -0.016162 & -0.195217 \\
Poor & $\mathbf{0 . 4 9 9 4 7 5 *}$ & 4.789238 \\
SquarePer & $-2.64 \times 10^{-06}$ & -0.236121 \\
Industry & 0.050860 & 0.362254 \\
HHSquare & $\mathbf{0 . 0 0 6 6 4 0 *}$ & 3.748030 \\
Log(House) & -0.053054 & -1.269372 \\
NonAgr & $\mathbf{0 . 5 5 6 3 9 7 *}$ & 2.600860 \\
Hunger & 0.004475 & 0.128053 \\
Log( & -0.314679 & -4.490192 \\
\hline Observations & 1010 & \\
McFadden R-squared & 0.052913 & \\
Log likehood & -656.4923 & \\
Prob(LR statistic) & 0.000000 & \\
\hline
\end{tabular}

Notes: $(*),(* *),(* * *)$ is significant at $1 \%, 5 \%, 10 \%$.

Average education level is characterized by the average years in school of household. Total living land owned can be used collateral for loans, more higher means more probability in accessing to loans. Otherwise, aging of household's head have negative impact on borrowing probability. More interestingly, we found that proportion of non-farm income and poor recognition by local is greater of gaining access to loans probability. It is argued that the households shift simple agriculture to non-farm or expanding production towards goods and services that induce demands of households for more loans. Poor households are beneficiaries of both policies and programs on poverty reduction of Vietnam government as well as of NGOs. Therefore, the poor recognition (or poor certificate) is necessary legal procedure for the poor households to access to formal credit sources.

\section{b. Result from Tobit model}

Testing the fit of the Mod.2 model results greater probability of Chi-squared value is 0.0000 that proved the model is appropriate. As we can see in Table 7 Tobit regression results, average of education level, farming land per capital, total assets, loan interest effect on value of loans from the formal sector.

Table 7. Determinants of access to formal rural credit by Tobit Regression

\begin{tabular}{|c|c|c|}
\hline \multirow{2}{*}{$\begin{array}{l}\text { Dependent variable } \\
\text { Explanatory variables }\end{array}$} & \multicolumn{2}{|c|}{ Log(Total Credit $)$} \\
\hline & Coefficient & z-Statistic \\
\hline$C$ & $6.766215^{*}$ & $(6.403994)$ \\
\hline Age & 0.001007 & $(0.360539)$ \\
\hline Gend & -0.033702 & $(-0.320642)$ \\
\hline Size & 0.016834 & $(0.705639)$ \\
\hline Minothic & 0.031071 & $(0.250628)$ \\
\hline$E d u$ & -0.000415 & $(-0.037493)$ \\
\hline Edu average & $0.038088 * *$ & $(2.373142)$ \\
\hline Depend & 0.023236 & $(0.408586)$ \\
\hline Poor & -0.006114 & $(-0.069338)$ \\
\hline Log(SquarePer) & $0.060153 * * *$ & $(1.746717)$ \\
\hline Industry & 0.144115 & $(1.501734)$ \\
\hline Log(HHSquare) & 0.077311 & $(0.0941179)$ \\
\hline Log(House) & $0.124456 *$ & $(2.771164)$ \\
\hline NonAgr & -0.018732 & $(-0.102851)$ \\
\hline Hunger & 0.042243 & $(1.438198)$ \\
\hline $\log ()$ & -0.004742 & $(-0.044208)$ \\
\hline Interest & $2.259683^{*}$ & $(3.140829)$ \\
\hline LivestockExpi & $-3.26 \times 10^{-6}$ & $(-0.540092)$ \\
\hline FosteryEXp & $2.44 \times 10^{-6}$ & $(0.885566)$ \\
\hline FarmExp & $-5.01 \times 10^{-6}$ & $(-0.392600)$ \\
\hline Observations & 462 & \\
\hline McFadden R-squared & & \\
\hline Log likehood & -435.6028 & \\
\hline Prob(LR statistic) & & \\
\hline
\end{tabular}


When looking at the Tobit regression we see that average of education level is significant within $90 \%$ confident level, y increasing one year in average of education level is giving gaining value of loan of $0.038088 \%$ respectively. This result can explain that more educated households either gain information or built business plan more than other (Khandker, S. R. and Faruqee, R. R., 2003). The result also indicates that policies directed towards increasing the flow of information may improve access to formal credit.

Land area per capita and residential area give a considerable higher value of loans from formal credit. At the $90 \%$ confident level, by gaining $1 \%$ in land area per capita squared, households receives the higher value loan of $0.060153 \%$; meanwhile, as result of $1 \%$ living land squared leading to achieve loan amount by $0.124456 \%$, at the $99 \%$ confident level. This indicates either that the ownership of land is very important for access to loan since to formal lenders normally require land use certificates as collateral for loans, or that households owning more farming land need more money (Quach, 2005). Pham and Lensinks (2007) also agreed that the availability of collateral is important in formal lending.

Our model also shows interest rate is significant within $90 \%$ confident level; consequence of going up $1 \%$ interest rate is achievement of loan amount by $0.02259683 \%$. The significant coefficients indicate that, in Northwest, there exists impact of interest rate on accessibility to formal credit. This result is different form previous studies argue that interest rate of formal credit has no statistically significant affect on the demand for formal credit (Anjani Kumar, 2010; Khandker and Faruqee, 2006; Kim, 2012).

In conclusions, out findings indicate that total value (land production per capital, living area) as collateral for loans and education level is greater of importance determinant of accessibility to formal credit. Interestingly, poor recognize certificates and non-farm income rate also gain probability to access credit by rural households in Northwest of Vietnam.

\subsection{Impact of Accessing to Credit on Living Standard}

For second research objective, the model mod 3 as the term used here by conducting DID approach with in ordinary least squares method. The regression results are reported in Table 8. As results of White test and LM test, we find that there is no heteroskedasticity and auto correlation in model.

Table 8. OLS Regression - Impact of formal credit on living standard: Case study about poor rural household 2010 2012

\begin{tabular}{|c|c|c|c|c|}
\hline Dependent variable & Thunhap & Chiluongthuc & Chigiaoduc & Chiyte \\
\hline Explanatory variables & Coefficient & Coefficient & Coefficient & Coefficient \\
\hline \multirow{2}{*}{$C$} & $-332.4848 *$ & 3.038438 & 873.4823* & -863.3991 \\
\hline & $(-3.602739)$ & $(-0.081759)$ & $(2.435024)$ & $(-0.867979)$ \\
\hline \multirow{2}{*}{$B$} & 30.00338 & 51.78439 & 171.0337 & 75.19726 \\
\hline & $(1.272239)$ & $(1.409221)$ & $(1.333454)$ & $(0.165518)$ \\
\hline \multirow{2}{*}{$T$} & $205.2869 \%$ & 282.4952* & $174.6745 * *$ & 186.5551 \\
\hline & $(7.670750)$ & $(6.338994)$ & $(2.010482)$ & $(0.843033)$ \\
\hline \multirow{2}{*}{$B^{*} T$} & -39.52974 & -6.113494 & $474.3665 * * *$ & 177.1789 \\
\hline & $(-0.871436)$ & $(0.081759)$ & $(1.735898)$ & $(0.344634)$ \\
\hline \multirow{2}{*}{$\log ($ Square $)$} & 80.07371* & 68.64896 & $-134.3032 *$ & 59.64757 \\
\hline & $(7.455760)$ & $(4.655704)$ & $(-2.936669)$ & $(0.528819)$ \\
\hline \multirow{2}{*}{$E d u_{-}$} & 2.274206 & $-17.49407 *$ & & 45.04168 \\
\hline & $(0.520973)$ & $(-3.236371)$ & & $(1.073117)$ \\
\hline \multirow{2}{*}{ Edu_average } & $17.54437 *$ & 47.51941* & & $106.8243 * * *$ \\
\hline & $(2.754335)$ & $(6.398817)$ & & $(1.676922)$ \\
\hline \multirow{2}{*}{ NonAgr } & $349.4888 \%$ & $143.1656 * *$ & -51.58954 & 534.5939 \\
\hline & $(7.029324)$ & $(2.282774)$ & $(-0.262001)$ & $(1.037341)$ \\
\hline \multirow{2}{*}{ Size } & $-14.46563 *$ & $-44.16982 *$ & $40.48437 * * *$ & 57.59670 \\
\hline & $(-2.779114)$ & $(-6.538504)$ & (1.76410) & $(1.050060)$ \\
\hline \multirow{2}{*}{ Age } & -0.388709 & 1.057481 & 2.504037 & -0.593526 \\
\hline & $(-0.410706)$ & $(0.916133)$ & $(0.832474)$ & $(-0.063562)$ \\
\hline Observations & 184 & 184 & 184 & 184 \\
\hline R-squared & 0.5357 & 0.5421 & 0.3449 & 0.1107 \\
\hline Prob(F-statistic) & 0.0000 & 0.0000 & 0.0000 & 0.0135 \\
\hline Prob(White-test) & 0.1332 & 0.3894 & 0.9841 & 0.2463 \\
\hline Prob(LM test) & 0.1106 & 0.1148 & 0.1053 & 0.3290 \\
\hline
\end{tabular}

Notes: t-Statistic in parenthese, $(*)$ Significant at 1\%, (**) Significant at 5\%, (***) Significant at $10 \%$ 
From Table 8 , at the $10 \%$ level of significance, only in model with dependent variable is expenditure on education, coefficient of $(\boldsymbol{B} * \boldsymbol{T})$ variable has statistically significant, by borrowing loans in 2012 leads to increased expenditure on education of 474.36 thousand VND per year. Besides, the insignificant coefficient of $(\boldsymbol{B} * \boldsymbol{T})$ variable in model with other dependent variable means there is not impact of credit on living standards in short-term, except expenditure on education. This result is supported by finding of Phan (2010). Phan (2010) offer an explanation that either poor household used borrowing loan for necessary purposes in short-tern such as loans payment, building house which is not affect on income. A second possible explanation is that the poor face variety drawbacks like education, land, production level, efficient business plan which is reason for low profitability of preferential loans. Although our explanation is surely not true for all cases, it can be justified with the facts that households in Northwest have lowest average income per capital which negatively affected on loans return. Interestingly, average of education level, land area capita, rate of non-farm income has greater influence in living standards, but size of household affected as opposed to living standards.

From Table 8, the significant coefficient of non-farm income rate on income capita per month and expenditure on food capita per month implies that non-farm income rate leads to enhance living standards of poor households in Northwest. Our finding supports some studies that non-agricultural production is better chance to increase income and reduce poverty for rural households in developing countries (LanjouwLanjouw 1995; Lanjouw, 1998; Ruben and Van den Berg, 2001).

At $1 \%$ significant, by increasing a year in average of education level in 2012 leads to increase on average of 17.54 thousand VND for income capital per month and 47.52 thousand VND for expenditure on food capita per month. The result confirms investing in education could help the poor better condition to get out of poverty in sustainable manner (Vuong (2012), David (2012).

On the factor of land production area, it is increased on average of 80.073 thousand VND for income capita by getting more $1 \%$ land production area by the same time decreased average of expenditure on education by 134.303 thousand VND. This finding implies that the area of household production increases could lead to drop of schooling; as the fact that their children have to stay at home to help their families or participate into farming activities.

Moreover, size of household has negative impact on living standards, as show in Table 8 . at the $90 \%$ confident level, increasing one person can deteriorate by 14.465 thousand VND for income capita, 44.16 thousand VND for expenditure on food capita, but increase 40.48 thousand VND for education. It is obviously that as consequence of increasing number of households, households living standards will decline. This result confirms the argument of World Bank (2012) that high birth rates and no family planning is the cause of poverty in mountainous areas or ethnic minority area in Vietnam.

\section{Conclusions and Recommendations}

\subsection{Conclusions}

This study investigates determinants of accessibility to formal credit in 2012 and its effects on living standards by using econometric framework: probit model and tobit model, DID approach. The findings confirm that total land area per capita, residential area owned, total assets, average of education level are positive factors of accessibility to formal credit; meanwhile, average of education level affects the probability to receive and size of loan. This result indicates that total owned land still is key factors that affect ability of receive loans by the poor households in Northwest of Vietnam. Indeed, formal lenders normally require land use certificate likely as collateral for loans. The significant coefficient of education variable in both Probit and Tobit model indicates that is a greater of important factor for borrowing loans. These was evidenced that more educated households tend to either make business plan efficiency than or gain information flow from formal credit (Khandker, 2003). In addition, interest rate is statistically significance, implying has positively impact of interest rate on loans amount. More interestingly, by analyzing econometric model, we find that rate of non-farm income and poor characteristics of household recognized by local is positively determinants of accessing to preferential credit.

Secondary, by using DID approach with in OLS regression, these results note that, in short-term, accessing to formal credit has no impact on living standards except expenditure on education. Somewhat, out findings can conclude that gaining accessibility to credit or providing preferential loans is not sufficient for poverty reducing, which is efficiency only if poor households are provided better consults and supports not only form banks but also from professional association in using capital. In addition, as results as, the positive influence of education level, production land, rate of non-farm income on living standards implied that investing on education, shifting on non-agricultural jobs or gaining land production is key factor for poverty alleviation in Northwest of Vietnam, which should be incorporated more with preferential credit programs. According the finding of Vuong (2012), David (2012), Ruben and Van den Berg (2001), we argued that investing on education and achievement of non-farm income rate is better condition to the poor in Northwest to get out of poverty faster and sustainably. 


\subsection{Recommendations}

Firstly, credit loan from formal credit as a financing channel to give opportunities to expand farm business, increase income, which can accelerate poverty reduction. However, besides providing fund, the banks or credit association should focus more on training on enterprenuership skills for the poor borrowers. Therefore, the Government of Vietnam should have policies which can consolidate both lending policy and suporting enterprenuership skills development for the poor households in Northwest:

Collateral is key factor that affects borrowing ability. However, reality shows that poor Northwest region often lack production land and lower total assets value, for these reasons, poor households cannot access to loans. So, to improve the accessibility to formal loan of the poor, the requirement for non-collateral or credit worthiness should be applied for small loans. Indeed, microfinance model of Grameen Bank, Bangladesh withs high interest rate, no collateral that is great effective, is best experience for Vietnam.

Secondly, Northwest area in Vietnam where has disadvantages about nature condition, shortage of production capacity, lack of education which is responsible for lower poverty rate annually and inefficiency of loans for poverty alleviation. The fact confirms that in order to improve the efficiency in using capital resource for poor and alleviate poverty faster and sustainably, Vietnam government needs to carry out credit programs strategically and combine reducing poverty program with programs to create jobs, provide enterprenuership skills for the poor.This opinion is also explained by finding in this study and previous studies such as Vuong (2012), Phan (2010). As results of study, shifting to non-agricultural jobs and gain higher education level is stark example, which give poor households favorable condition to increase living standards namely income per capita and expenditure on foods. Indeed, two countries in Asian like Thailand and Malaysia have achieved encouraging results in poverty alleviation by performing very successfully missions that improve learning ability of community and improve education attainment.

Finally, the findings from this research showing that investment in education will help to increase the income of the borrowers. Therefore, to eliminate the poverty in the North of Vietnam, the Government should focus more on the policy to support for education development in this area, the household should recognize the impact of education on their living standards do that they can borrow or invest in their children education.

\section{References}

ADB. (2000). Finance for the Poor: Microfinance Development Strategy. Asian Development Bank. Retrieved from $\mathrm{http} / / / \mathrm{www}$.adb.org/documents/finance-poor-microfinance-development-strategy

Anjani, K., Singh, K.M., \& Shradhajali, S. (2010). Institutional Credit to Agriculture Sector in India: Status, Performance and Determinants. Agricultural Economic Research Review, 23. Retrieved from http://ageconsearch.umn.edu/bitstream/96935/4/6-Anjani-Kumar.pdf

David, E. (2012). Access to Rural credit and its effects on Income Equality: Study about rural households in Vietnam. Retrieved from https://lup.lub.lu.se/student-papers/search/publication/3021603

Fuwa, N., Ito, S., Kubo, K., Kurosaki, T., \& Sawada, Y. (2009). How Does credit Access Affect Children's time allocation? Evidence from Rural India. IDE discussion paper No. 183.

George, O. (2010). The analysis of the rural Credit market in Ghana. International Business \& Economics Research Journal. Retrieved from http://www.cluteinstitute.com/ojs/index.php/IBER/article/view/611

Khandker, R. P. (2003). Credit programs for the poor and the health status of children in rural Bangladesh. International Economic Review, 44(1), 87-118.

Khandker, S. R. (1998). Fighting Poverty with Microcredit: Experience in Bangladesh. New York, Oxford University Press, Inc.

Khandker, S. R. (2001). Does Micro - Finance Really Benefit the Poor? Evidence from Bangladesh. Asia and Pacific Forum on Poverty: Reforming Policies and Institutions for Poverty Reduction, Asian Development Bank. Manila, Philippines.

Khandker, S. R. (2003). Microfinance and Poverty: Evidence Using Panel Data from Bangladesh. World Bank Policy Research Working Paper 2945.

Khandker, S. R. (2009). Welfare Impacts of Rural Electrification: An evidence from Viet Nam. World bank. Retrieved from

http://econ.worldbank.org/external/default/main?pagePK=64165259\&piPK=64165421\&theSitePK=544849\&m enuPK=64216926\&entityID $=000158349 \_20090917100619$ 
Khandker, S. R., \& Faruqee, R. R. (2003). The impact of farm credit in Pakistan.

Kim, M. (2013). Rural Poverty alleviation in Burma's Economic Strategy: A Comparative Evaluation of Alternative Interventions to Increase Rural Access to Capital. Retrieved from http://dukespace.lib.duke.edu/dspace/handle/10161/6666

Lanjouw, J. O., \& Lanjouw, P. (1995). Rural nonfarm employment: A survey. Policy Research Working Paper, 1463. The World Bank.

Mikkel, B., \& Finn, T. (2003). Rural Credit in Vietnam. Retrieved from http://www.econ.ku.dk/wpa/pink/2006/0603.pdf

Mikkel, B., \& Finn, T. (2008). Formal and informal rural credit in four provinces of Vietnam. Retrieved from http://www.econ.ku.dk/Research/Publications/pink/2007/0707.pdf

Morduch, J. (2002). Analysis of the Effects of Microfinance on Poverty Reductio. Working Papers Series.

Morduch, J. (2005). The Economic of Microfinance. Massachusetts Institute of Technology, USA

Nguyen, C., Phung, T., Phung, T., Vu, N., \& Westbrook, D. (2012). The Impact of National Poverty Reduction Program on Ethnic Minorities in Vietnam: The lens of Baseline and Endline Surveys. Mekong Development Research Institute. Retrieved from http://mpra.ub.uni-muenchen.de/50477/

Nguyen, T. T. H. (2010). Rural credit market in Vietnam.

Pham, T. T. T., \& Lensink, R. (2007). Lending policies of informal, formal and semiformal lenders.

Pitt, M., \& Khandker, S. R. (1998). The impact of group-based credit program on poor households in Bangladesh: Does the gender of participants matter?. Journal of Political Economy, 106, 958-996. Retrieved from http://links.jstor.org/sici=0022-3808\%28199810\%29106\%3C958\%3ATIOGCP\%3E2.0.CO\%3B2-8

Quach, M. H, A., Mullineux, W., \& Murinde, V. (2005). Access to credit and household poverty reduction in rural Vietnam: A cross-sectional study.

Tobin, J. (1959). Estimation of Relationship for Limited Dependent Variables. Econometrica, 26.

Vuong, Q. D. (2012). Determinants of household access to formal credit in the rural areas of the Mekong Delta, Vietnam. African and Asian studies, 11, 261-87. http://dx.doi.org/10.1163/15692108-12341234

Vuong, Q. D. (2012). Impact of differential access to credit on long and short term livelihood outcomes: group - based and individual microcredit in the Mekong Delta of Vietnam. Retrieved from http://www.econbiz.de/Record/impact-differential-access-credit-long-short-term-livelihood-outcomes-group-ba sed-individual-microcredit-mekong-delta-vietnam-vuong-quoc-duy/10010203103

WB. (2004). World Development Report 2004.

Zeller, M., \& Diagne, A. (2001). Access to credit and its impact on welfare in Malawi. International Food Policy Research Institute, Washington D.C.

Zeller, M., \& Sharma, M. (2006). Rural Finance and Poverty Alleviation. A Policy Report of International Food Policy Research Institute, Washington DC, USA. p. 5-30.

\section{Notes}

Note 1. In this study, the Northwest provinces including local direction subject of the Northwest Steering Committee (Lai Chau, Dien Bien, Son La, HoaBinh, Cao Bang, Lang Son, BacKan, Ha Giang, TuyenQuang, PhuTho, Lao Cai, and Yen Bai).

Note 2. Difference in Difference.

Note 3. Ordinary Least Squares.

Note 4. According to the investigation, reviewing poor and near poor households in 2012 of the Ministry of LabourInvalids and Social Affairs, the national poverty rate was 9.6\%; The Northwest (21.54\%), The Red river delta (4.58\%); North Central (15.01\%); Central Coast (12.20\%); Tay Nguyen (15.00\%); Southeast (1.27\%); Cuu Long River Delta (9.24\%).

Note 5. Formal credit (including: the Vietnam Bank for Agriculture and Rural Development (VBARD), Vietnam Bank for Social Policies (VBSP), and other commercial banks); Semi-formal credit (including: credit institutions, political organizations, other loans); informal credit (including: individual lenders, friends, relatives). 